DOI https://doi.org/10.18551/rjoas.2020-10.20

\title{
PUBLIC PERCEPTION INDEX ON SYSTEM, MECHANISM, AND PROCEDURE OF GETTING TRADING LICENSE AT INVESTMENT AND ONE STOP INTEGRATED SERVICE OFFICE OF PAMEKASAN REGENCY, INDONESIA
}

\author{
Basyarahil Abubakar, Ma'mun Sukron, Saputri Erina, Husein Mohammad Bustanol \\ Study Program of Public Administration, Faculty of Administrative Sciences, \\ Madura University, Indonesia \\ *E-mail: abubakar061260@gmail.com
}

\begin{abstract}
Measuring public perception index of certain public service is considered to be important if we want to determine its quality. Mostly, people consider that mechanism and procedure of getting trading license need more concern because the service is sometimes difficult and needs longer time. This study is aimed to measure public perception index on system, mechanism and procedure of getting trading license at Investment and One Stop Integrated Service Office at Pamekasan Regency. The method used in this study was survey in reference to the Regulation of the Minister of Administrative Reform and Bureaucratic Reform of the Republic of Indonesia Number 14 of 2017 about guidelines for arranging survey of public perception unit. One of the indicators of public perception is related to system, mechanism and procedure. The result of this study shows that service of getting trading license in Pamekasan is good.
\end{abstract}

\section{KEY WORDS}

Public perception, service procedures, investment, one stop integrated service office.

Basically, people want a fast, easy and efficient public service. But in reality, they often face complicated system of public service. Their dissatisfaction on getting public service is caused by maladministration. However, system, mechanism or procedure of public service becomes a benchmark that should be noticed. In this case, Investment and One Stop Integrated Service Office at Pamekasan Regency is one of institution which provides public service. As a public institution, it surely has its own system, mechanism and procedure service.

People sometimes do not understand about the system and procedure of a public institution. While as service provider, the government official should provides a simple and good service for the people. But in reality, not all of them are able to explain and to give responsive service about the system, mechanism and procedure for public.

Based on the problem above, the researcher wanted to do a study about public perception on system, mechanism and procedure of getting trading license at Investment and One Stop Integrated Service Office at Pamekasan Regency since the result of this study can be used as a reference to give a better service.

Based on the statements of the problem mentioned above, the objective of this research is to describe public perception index on system, mechanism and procedure of getting trading license at Investment and One Stop Integrated Service Office at Pamekasan Regency.

The research is highly expected to give contribution to public as a description in getting trading license and it is also expected to be a valuable reference in improving the service's quality of getting trading license at Investment and One Stop Integrated Service Office at Pamekasan Regency.

\section{METHODS OF RESEARCH}

This research is intended to measure public perception which is focused on system, mechanism and procedure of getting trading business license at investment and one stop 
integrated service at Pamekasan regency. To collect data, the researcher conducted a survey to the research sample from April up to August of 2019.

The following steps had been done in conducting the research, as follows: Planning; Determining Location of Study.

Since this research wanted to measure public perception about system, mechanism and procedure of get trading business license, this research was conducted at Investment and One Stop Integrated Service Office (DPMPTSP) of Pamekasan Regency.

The Regulation of the Minister of Administrative Reform and Bureaucratic Reform of the Republic of Indonesia Number 14 of 2017 become guidelines for arranging survey of public perception unit. It was carried out through the stages of preparation, implementation, data processing and data presentation as the following steps: developing instruments; determining respondents; conducting research; processing the result of research; presenting and reporting the result of research.

Data were collected by using mix method. It is a combination of Qualitative and Quantitative method in one way (Sugiyono, 2011:18). This kind of method was used to get more comprehensive, valid, realable and objective data.

Interviewing respondents was a way to get qualitative data, while to get qualitative data; the researcher gave questionnaires to respondents.

Likert Scale Measurement. Each question on the instrument in this study was scored based on Likert scale as follows:

- Score 1 means the service is very poor;

- Score 2 means the service is poor;

- Score 3 means the service is fair;

- Score 4 means the service is good.

If there are some questions that are not filled by the respondent, it will affect on the average value (NRR) of system, mechanism and service's procedure.

$$
\text { Average Value }=\frac{\text { total value }}{\text { total score of questionaire }}
$$

Firstly, the researcher determined a weighted average of sytem, mechanism and service procedure before calculating public perception index. From the calculation, known that those data had a same weighted average. It determined by using this following formula:

$$
\text { Weighted Average }=\frac{\text { total weights }}{\text { total elements }}=\frac{1}{1}=1
$$

Weighted average is used to obtain the value of public perception index, as the following formula:

\section{Weighted Average $=$ Average Value $(N R R) \times 1$}

To make easier on interpretation the index of public perception that has a range between 25-100 point, so the total value is converted into 25 as the following formula:

Public Perception Index $=$ Total average value $\times 25$

Considering that each service unit has different characteristics, and then it should make adjustment as follows: adding some relevant elements to service unit that wanted to be measured; giving higher point on dominant element of each service by considering that the amount point of all elements used is fixed; if there is no dominant element that would be ranked, each element is given a same point.

To analyze data, this study used two ways as follows:

- Computer Processing. The data got from this research were analyzed by using computer program or database system. 
- Manual Processing: the researcher input the data of the questionnaire into a specific form according to the elements being assessed; the next step was calculating the average value and the obtained value of system, mechanism and procedure of public perception, and then examining their qualities.

Validity and Reliability Test. A test is valid if it measures what it claims to measure. This research wants to measure about public perception index on system, mechanism and procedure of getting trading license at Investment and One Stop Integrated Service Office at Pamekasan Regency, so validity test was also conducted in this study.

Reliability test was also applied in this research to know how consistently the respondents' answer under the same conditions as their consistent answer affects on the result of data. If the researcher applied the same method to the same sample under the same conditions and he/she gets the same results, it means that the method of measurement is reliable.

\section{RESULTS AND DISCUSSION}

The data from questionnaire were inputted into the following table:

Table 1 - Data Tabulation of Public Perception on System, Mechanism, and Procedure of Getting Trading License at investment and one stop integrated service at Pamekasan regency

\begin{tabular}{|c|c|c|c|c|c|}
\hline Respondent's Number & Score & Category & Respondent's Number & Score & Category \\
\hline 1. & 2 & poor & 37. & 3 & fair \\
\hline 2. & 3 & fair & 38. & 3 & fair \\
\hline 3. & 3 & fair & 39. & 3 & fair \\
\hline 4. & 1 & very poor & 40. & 3 & fair \\
\hline 5. & 3 & fair & 41. & 3 & fair \\
\hline 6. & 3 & fair & 42. & 3 & fair \\
\hline 7. & 2 & poor & 43. & 3 & fair \\
\hline 8. & 2 & poor & 44. & 3 & fair \\
\hline 9. & 4 & good & 45. & 1 & very poor \\
\hline 10. & 3 & fair & 46. & 2 & poor \\
\hline 11. & 3 & fair & 47. & 4 & good \\
\hline 12. & 3 & fair & 48. & 4 & good \\
\hline 13. & 3 & fair & 49. & 4 & good \\
\hline 14. & 4 & good & 50. & 3 & fair \\
\hline 15. & 4 & good & 51. & 1 & very poor \\
\hline 16. & 3 & fair & 52. & 3 & fair \\
\hline 17. & 3 & fair & 53. & 3 & fair \\
\hline 18. & 3 & fair & 54. & 3 & fair \\
\hline 19. & 3 & fair & 55. & 4 & good \\
\hline 20. & 3 & fair & 56. & 2 & poor \\
\hline 21. & 2 & poor & 57. & 4 & good \\
\hline 22. & 2 & poor & 58. & 4 & good \\
\hline 23. & 4 & good & 59. & 4 & good \\
\hline 24. & 4 & good & 60. & 3 & fair \\
\hline 25. & 3 & fair & 61. & 4 & good \\
\hline 26. & 3 & fair & 62. & 3 & fair \\
\hline 27. & 3 & fair & 63. & 3 & fair \\
\hline 28. & 4 & good & 64. & 3 & fair \\
\hline 29. & 3 & fair & 65. & 3 & fair \\
\hline 30. & 3 & fair & 66. & 3 & fair \\
\hline 31. & 3 & fair & 67. & 4 & good \\
\hline 32. & 1 & very poor & 68. & 3 & fair \\
\hline 33. & 4 & good & 69. & 4 & good \\
\hline 34. & 3 & fair & 70. & 3 & fair \\
\hline 35. & 3 & fair & 71. & 4 & good \\
\hline 36. & 2 & poor & Total Score & 224 & - \\
\hline
\end{tabular}

Based on the table above, it was shown that the total score of public perception was 224 of 71 respondents. 
Table 2 - Result of Public Perception on System, Mechanism, and Procedure of Getting Trading License at investment and one stop integrated service at Pamekasan regency

\begin{tabular}{|c|c|c|c|}
\hline Elements & Average Value & Weighted Average & $\begin{array}{c}\text { Public Perception } \\
\text { Index }\end{array}$ \\
\hline $\begin{array}{c}\text { System, Mechanism, and } \\
\text { Procedure }\end{array}$ & $\begin{array}{c}\text { Total Value: Total Score of } \\
\text { Questionnaire } \\
=3,1549\end{array}$ & $\begin{array}{c}\text { Weighted Average }=\text { Average } \\
\text { Value (NRR) } \times 1\end{array}$ & $\begin{array}{c}\text { Total Average } \\
\text { Value } \times 25 \\
=78,8725\end{array}$ \\
\hline
\end{tabular}

Based on the table above, it was known that public perception on system, mechanism and procedure of getting trading license at Investment and One Stop Integrated Service Office (DPMPTSP) of Pamekasan Regency had total score 78.8725 so if we converted it into value of service quality interval, it was categorized as good service with total average value of 3,1549 .

Table 3 - Value of Service Quality Interval

\begin{tabular}{|c|c|c|c|c|c|}
\hline Number & $\begin{array}{c}\text { Perceived } \\
\text { Value }\end{array}$ & $\begin{array}{c}\text { Small and Medium } \\
\text { Industry Interval Value }\end{array}$ & $\begin{array}{c}\text { Service } \\
\text { Quality Value }\end{array}$ & $\begin{array}{c}\text { Service Quality } \\
\text { Category }\end{array}$ & $\begin{array}{c}\text { Service Unit } \\
\text { Performance }\end{array}$ \\
\hline 1. & 1 & $1,0000-2,5996$ & $25,00-64,99$ & D & Very Poor \\
\hline 2. & 2 & $2,6000-3,0640$ & $65,00-76,60$ & C & Poor \\
\hline 3. & 3 & $3,0644-3,5320$ & $76,61-88,30$ & B & Good \\
\hline 4. & 4 & $3,5324-4,0000$ & $88,31-100,00$ & A & Very good \\
\hline
\end{tabular}

Source: Permenpan Number 14 of 2017.

Based on those three tables, it was found that public perception on system, mechanism and procedure of getting trading license at Investment and One Stop Integrated service office (DPMPTSP) of Pamekasan Regency had total score 78.8725, it was categorized good.

\section{CONCLUSION}

Based on data analysis of public perception on system, mechanism and procedure of getting trading license at Investment and One Stop Integrated Service Office of Pamekasan Regency had total score 78.8725 so it was categorized as good service. Investment and One Stop Integrated Service Office at Pamekasan Regency delivers good service for public who want to get trading license index. The system, mechanism and procedure are understandable and it does not take a long time for getting the service, so it can prevent from maladministration. Although it delivers good service so far, Investment and One Stop Integrated Service Office at Pamekasan Regency should improve its service to reach highest quality.

\section{REFERENCES}

1. Abdurahman. 2018. Capacity Building Aparatur Sipil Negara Untuk Mewujudkan Democratic Local Governance. Univeritas Airlangga. Surabaya

2. Gaspersz, Vincent. 2005. Total Quality Management. PT. Gramedia. Pustaka Utama. Jakarta.

3. Sinambela, Lijan Poltak. Dkk. 2011. Reformasi Pelayanan Publik. Bumi Aksara. Jakarta.

4. Sugiyono. 2011. Metode Penelitian Kuantitatif, Kualitatif, and R\&D. Alfabeta. Bandung.

5. Krejcie, R. V., \& Morgan, D. W. 1970. Determining Sample Size for Research Activities. Educational and Psychological Measurement

6. (2017) Peraturan Menteri Pendayagunaan Aparatur Negara and Reformasi Birokrasi Republik Indonesia Nomor 14 Tahun 2017 Tentang Pedoman Penyusunan Survei Kepuasan Masyarakat Unit Penyelenggara Pelayanan Publik. 